\title{
Students' Motivation and Appreciation on The Teaching of Writing Short Story Based on Creative-Literacy
}

\author{
Sitti Rachmi Masie ${ }^{1}$, Wahyudi Siswanto ${ }^{2}$, Yuni Pratiwi ${ }^{3}$, Heri Suwignyo ${ }^{4}$ \\ ${ }_{1}^{1}$ Pendidikan Bahasa dan Sastra Indonesia Universitas Negeri Gorontalo \\ Email: sirachma80@gmail.com \\ ${ }^{2}$ Pendidikan Bahasa Indonesia, Universitas Negeri Malang \\ Email:wahyudi@um.ac.id \\ 3Pendidikan Bahasa Indonesia, Universitas Negeri Malang \\ Email:_yuni.pratiwi@yahoo.com \\ ${ }^{4}$ Pendidikan Bahasa Indonesia, Universitas Negeri Malang \\ Email: heri.suwignyo.fs@um.ac.id
}

(Received: October-2017; Reviewed: November-2017; Accepted: December-2017; Published: December-2017)

C2017 -EST Graduate Program Universitas Negeri Makassar. This is an article with open access under license CC BY-NC-4.0 (https://creativecommons.org/licenses/by-nc/4.0/ ).

\begin{abstract}
This paper is initiated by the writers' preliminary observation regarding literary work learning activities in the Department of Indonesian Education and Literature State University of Gorontalo, which is still experiencing problems in its learning process. One of the obstacles faced is that students are still lack of confidence in developing their ability to write literary works, especially writing short stories. Writing short stories based on creative literacy is a strategy given to develop the competence of learners in writing. Short story is chosen because it has an interesting characteristics so students will easily read and understand it. Using this strategy, it is expected that students are able to write short stories based on the results of their own creation. Writing short stories based on creative literacy can manifest students' ability in identifying various text forms, the purpose of the text, the text readers' target, and it enables the students to use their thinking ability to organize their process of reading and writing their new work.
\end{abstract}

Keywords: motivation; appreciation; short story writing; creative literacy.

\section{INTRODUCTION}

Learners motivation in learning lies in the achievement of successful management of the world of education. Motivation is formulated as an encouragement coming from both the inside and outside of the learners or it is called as intrinsic and extrinsic motivation. Extrinsic motivation refers to the motivation to engage in one activity as a means to an end. Meanwhile, intrinsic motivation is the motivation to engage in the ongoing activities lies in the learners themselves. In general, learners are motivated because they are able to process information in depth, persistent in doing tasks, and have a positive attitude towards education.

According to Jensen (2010: 24) motivation has a function to encourage postitive relationships between educators and learners, build relationships between educators and learners, stimulate thoughts, creativity, and curiosity, and increase self-esteem, confidence, and value from students.

The importance of the role of motivation in the learning process needs to be understood by educators in order to perform various forms of action or assistance to learners. The role of motivation in the learning process, 
according to Eggen and Don Kauchak (2012: 69 ) is the behavior and confidence of educators, order and security, effective teaching, helping learners to succeed, creating a sense of challenge, making the sample more personal, and involving learners. Through this concept, it can be understood that it is important for the educators to prepare the competence as a form of responsibility to let the learners learn by themselves in achieving their goals.

The process of learning in universities, especially in the Department of Indonesian Education and Literature State University of Gorontalo needs more attention concerning the teaching of literary work writing . The literary work writing course is a course that aims at developing student's competence to produce creative and innovative works of various forms of literary works. In general, there have been many literary works that have motivated the reader and have gaven a picture or criticism to an unbalanced state also have influenced the reader to be interested in participating in the world of literature .Therefore, by the end of completing the course, students are expected to have high motivation and appreciation toward literary work writing competence.

The essence of writing literary work lies on the writing through creative work processes. Creative writing according to Laksana (2013: 4) is creating or building a world, involving emotions and conscience in it, and as a 'ruler' for a life it creates including novels, short stories, poetry, and more. Creative writing is included into fiction or fiction containing insignificant data or facts as the data can be used as a point of departure but it not absolute as the logic is typical characteristics of fiction or imaginary fiction. The process of creating literary works is part of the appreciation of literary works.

Appreciation on the literary works aims at providing an assessment of literary works. If you appreciate a literary work, it is necessary to have a process of observation activities, assessment, and award giving concerning the literary work you have read. According to Sayuti (2009: 8) the appreciation of literature is the result of the reader's efforts in finding and discovering the true value of literary works through systematic understanding and interpretation which can be expressed in written form. Stages of appreciation include: (1) recognition and enjoyment stage which is an action in the form of reading, seeing or watching and listening to a literary work; (2) appreciation stage which describes one's feeling on the usefulness or benefits of literary works, such as giving pleasure, and entertainment, (3) understanding stage which is in the form of doing research and analysis regarding the elements building the literary works, both intrinsic and extrinsic elements, (4) appreciation stage which is a stage of making interpretation of literary works, and (5) application stage which is a stage describing the realization of values obtained from the literary work concerning one's attitude and everyday behavior.

However, the interests of learners in literature are now likely to experience stagnation or congestion. This makes literary works sometimes are underestimated. Yet with literary works, students will be more creative in processing words, exploring the language, and making the language as the main reference for community to move forward. Language in fact is part of the culture, because the language is also used to convey the message of culture to other nations.

Today the interest of writing literary works for students, especially in the Department of Indonesian Education and Literature State University of Gorontalo tend to decrease, so it needs to be improved so that they are able to maintain their ability in writing the liteary work. It is expected that the students will not only see literature as merely a demands of duty or hobby, but it is also expected that literary work can be used as an innovative positive culture. Some of the factors that hinder students learning on writing literary work are (1) students are lack of interest in reading, (2) students do not practice writing, (3) students regard literary writing as the subject for a demanded task that must be fulfilled not as one of the ways to train their competence, (4) lecturers have too many students and they are not always able to fulfill every students'needs.

Through this research, researchers try to give one contribution to the development of writing one literary work, especially on the aspect of writing prose or story. Through the analysis of motivation and appreciation of students to the writing of literature, researchers hope to improve learning both from learning motivation, learning process, learning strategy and the assessment. It is expected to be able to 
increase the interest and learning outcomes of students of Department of Indonesian Education and Literature State University of Gorontalo .

One of the literary works which becomes much of students' concern is short story. The learning of short story writing is learned by using creative literacy-based concepts. Creative literacy is the integration of skills in understanding ideas and information by using conventional text forms as well as innovative texts, symbols and multimedia. According to Abidin (2015: 51), to be able to literary sensitive in the information age, one must be able to engage in literacy practices and be able to describe the various literacy skills in diversity. With this variety of literacy, one can take the concept of creative thinking.

The creative writing process cannot be separated from reading. Writing process requires the students to read various references from books, articles, newspapers, magazines, journals and others. They may create their own literary work based on their sense of curiosity and sensitivity in seeing the reality around the environment. Curiosity is the writer's primary capital. Every idea of writing is born because the writer wants to know something or the response to the reality around him. Hasanah and Siswanto (2013: 26) explained that in the process of writing, various aspects of psychology of the writer play an active role in influencing the creative process. Those psychological aspects are (1) attention, (2) observation, (3) responses, (4) fantasy, (5) memories, (6) thoughts, (7) feelings, and (8) other motives.

The activities based on creative literacy according to Haven (2005), is a learning of writing which is oriented to get the following learners' competence (1) Having awareness means that students are able to ask questions, explore, and research, explore ideas and thoughts, and adapt, (2) mastering the structure of text, understanding the text, and being able to give the meaning of the text that is read and made, enjoying reading activities, criticizing text, and enjoying writing activities, (5) being able to revise and edit their writing because there is no instantly good writing for the first draft, (6) mastering technical writing.

This research is conducted to describe the motivation and appreciation on students' competence in writing the story of literary work writing course. The literary work writing course concerns with the problem on material construction taught, methods, media, teachinglearning interaction, and assessment applied in the Department of Indonesian Education and Literature State University of Gorontalo.

\section{RESEARCH METHOD}

This research is a qualitative research using descriptive method. Qualitative nature of this research leads to discussion of issues about motivation and appreciation of students in learning short story writing in the Department of Indonesian Education and Literature State University of Gorontalo. Then, there are three steps undertaken to solve this research problemas follow; (1) data provision, (2) data analysis, (3) presentation of data analysis result (Sudaryanto, 1993: 5).

The data in this research were taken from the students of Department of Indonesian Education and Literature State University of Gorontalo. The data was obtained from the students with the following consideration; (1) the student has already taken a course on literary work writing , (2) the student is actively taking part in literary work writing course

The research data were collected by using questionnaire method. To fulfill the validity of the data, the researchers used the criteria of content validity, that is the fulfillment of the validity aspect by preparing the statement items based on the problems and research indicators that have been found through previous observations, so that the statements in the questionnaire are according to the substance of the problem studied.

The analysis of research data concerning motivation and appreciation of students in the literary work writing was done using qualitative analysis through the following steps; data reduction, data display, and conclusion drawing with verification.

After obtaining the data from observations and questionnaires, the researchers then performed an analysis to determine the motivation score of students' learning. The results of observational data analysis was presented in the form of descriptive explanation. To do quantitative analysis, the following steps are taken. a) Determining the criteria of scoring on each descriptor on each aspect of student learning motivation observed. b) Summing the scores for each aspect of learning motivation observed. c) Calculating the score of learning 
motivation in every aspect observed by the following formula:

Maximum score

(Sugiyono, 2010: 137)

score result of students' motivation

The steps to analyze the questionnaire data of motivation to learn in this research is as follow. a. Calculating the motivation questionnaire score for each student

Table 1.1 The motivation questionnaire score

\section{The Category of Respondents' Answer}

Score of Each Item

\begin{tabular}{ll}
\hline Very good & 4 \\
\hline Good & 3 \\
\hline Sufficient & 2 \\
\hline Insufficient & 1 \\
\hline
\end{tabular}

b. Calculating the percentage of student motivation to learn

c. Giving meaning on the use of assessment criteria according to Arikunto (2009: 242) as follows.

Table 1.2 The assessment criteria

\begin{tabular}{cc}
\hline Percentage & Criteria \\
\hline $85-100$ & Very high \\
\hline $70-84$ & high \\
\hline $55-69$ & Low \\
\hline $0-54$ & Very low \\
\hline
\end{tabular}

\section{RESULTS AND DISCUSSION}

\section{Results}

Motivation aspect expressed in this research is the usefulness of learning process to improve student's learning motivation in writing short story. In this case, it includes the process of: prewriting, while-writing, and post writing.

Short story writing is a learning that emphasizes students' ability to perform a series of writing activities based on empowerment of imaginative ability to think creatively. In the pre-writing stage, the results show that students are able to determine the type of text, analyze the text, invent their needs, and build the framework of the story. In the stage of short story writing, students are able to change the form of text into a storyline, and write stories based on text elements. At the post writing stage, students are able to present, edit, and revise their work.

The results of the calculation of the score through the questionnaire grid on students' learning process of short story writing course are as follows

Table 1.3 The results of the calculation of the score

\begin{tabular}{llccccc}
\hline No & Component & $\begin{array}{c}\text { Number } \\
\text { Item }\end{array}$ & $\sum$ & $\begin{array}{c}\text { Maximum } \\
\text { Score }\end{array}$ & $\%$ & Criteria \\
\hline $\mathbf{1}$ & $\begin{array}{l}\text { Pre writing ( Short story) } \\
\text { (Determining types of } \\
\text { works, analyzing text } \\
\text { elements, inventory needs, } \\
\text { building frameworks) }\end{array}$ & 7 & 635 & 700 & 92.71 & Very high \\
& & & & & \\
\hline
\end{tabular}




\begin{tabular}{cllllll}
\hline $\mathbf{2}$ & $\begin{array}{l}\text { While writing (short story) } \\
\text { (Changing works, arranging } \\
\text { the storylines, writing } \\
\text { storylines based on story } \\
\text { elements) }\end{array}$ & 16 & 1342.5 & 1600 & 83.91 & High \\
\hline $\mathbf{3}$ & $\begin{array}{l}\text { Post writing (short story) } \\
\text { (Presenting, editing, and } \\
\text { revising their works) }\end{array}$ & 8 & 707.5 & 800 & 88.41 & Very high \\
\hline Total & $\mathbf{3 1}$ & & & & \\
\hline
\end{tabular}

The results score regarding students'answers on their motivation in literary work writing course obtained from questionnaire on each indicator are described as follow. (1) there are 7 item statements indicator regarding short story in the pre-writing stage. The result of score calculation is: the total score obtained is 632, maximum score is equal to 700 , score percentage is equal to $92.71 \%$. So it can be said that the student's motivation indicator measured on pre writing stage is very high.(2) there are 16 item statements indicator regarding short story in the while-writing stage. The result of score calculation is: total score obtained is 1342.5 , maximum score is 1600 , and the percentage score is $83.91 \%$. So it can be said that the student's motivation indicator measured on while writing stage is very high.(3) there are 7 item statements indicator regarding short story in the post-writing stage.
The result of score calculation is: the total score obtained is 707.5 , the maximum score is 800 , the percentage score is $88.41 \%$. So it can be said that the student's motivation indicator measured on post-writing stage is very high.

The items of questionnaire item that has the lowest score is at position number 17 with the amount of 30 or $75 \%$, namely at the stage of writing regarding the ability to arrange the story line. While the questionnaire item that has the highest score is at number 22 with the amount of 39 or $97.5 \%$ ie at the stage of the implementation of the writing process regarding the statement stating that lecturer's guidance and motivation in teaching literary work writing course. The result of questionnaire score of student motivation questionnaire in the course of writing the literary works is as follows.

Table 1.4 The results of the calculation of the score

\begin{tabular}{rcccl}
\hline Students & $\sum$ & Maximum score & $\mathbf{\%}$ & Criteria \\
& & & & \\
\hline $\mathbf{1}$ & 99 & 124 & 79.84 & High \\
\hline $\mathbf{2}$ & 113 & 124 & 91.13 & Very high \\
\hline $\mathbf{3}$ & 113 & 124 & 91.13 & Very high \\
\hline $\mathbf{4}$ & 105 & 124 & 84.67 & High \\
\hline $\mathbf{5}$ & 110 & 124 & 88.71 & Very high \\
\hline $\mathbf{6}$ & 103 & 124 & 83.06 & High \\
\hline $\mathbf{7}$ & 108 & 124 & 87.09 & Very high \\
\hline $\mathbf{8}$ & 108 & 124 & 87.09 & Very high \\
\hline $\mathbf{9}$ & 109 & 124 & 87.90 & Very high \\
\hline $\mathbf{1 0}$ & 100 & 124 & 80.65 & High \\
\hline Mean & & & 861.27 & \\
\hline & & & $=86.13$ & \\
\hline
\end{tabular}


The following is the description of the data obtained regarding students' motivation and appreciation in each learning process. From 10 student respondents, 6 students have very high motivation and appreciation while 4 other students have high criteria. The lowest score of students is 99 or $79.84 \%$, while the highest is 113 or $91.13 \%$. This shows that there are several stages that make up students and lecturers concern during the learning process of short story writing.

\section{Discussion}

From the table it can be seen that the pre writing components cover the components of students' understanding related to a variety of literacy, form of text, text analysis. In the learning process component of story writing includes the development of story framework, creative writing process, creativity opportunity, cooperation, assignment, and guidance. While in the post-writing stage there is a need for revising, reflecting and awarding the students for the work they have made.

The implementation of short story writing is considered maximum if the teachers act as a designer, motivator, facilitator, model, and counselor. Therefore, they can provide the creation of an optimal learning climate. Optimal learning has an impact on the successful implementation of learning to write one types of literary work especially short stories. The success of learning to write a story can be achieved if there is a match between facts, symptoms, or something learned with the level of development of thinking power, imagination, and creativity of students. Such suitability provides an opportunity for internalization with respect to what is learned and the opportunities of adaptation with the knowledge base. Students' ability is obtained through reading, appreciating, giving short story text, giving structure card, using group learning strategy and varied individual learning, brainstorming, story grouping, lecturer's guiding, engraving and revision.

Related research in line with this current research. Julaeha (2013) conducted a study on the effort in improving the student's abilityto write creative short story through image sugesty strategy. The steps in this lesson go through the following stages; (1) building students' motivation and interest by reading the example of the story, (2) building student's imagination through music and song, (3) creating a process through imagination, and (4) editing process.

Erstad (2009) also conducted a study on the concept of understanding and introducing a variety of literacy texts by testing students' early abilities with regard to learning styles and types of intelligence as well as multimedia literacy capabilities and a variety of multimodal texts.

Another research in line with this current study was also done by Sultan, Rofiuddin, Nurhadi, and Priyatni (2017) who did a research on the use of critical literacy on students and the results were proven to be able to improve students'learning outcome. The critical literacy approach guides readers to question information, perspective assumptions, and the purpose of the writer.

\section{CONCLUSION AND SUGGESTION}

Based on the results of research and discussion, there are some conclusions taken as follow: Motivation of student learning by applying of questionnaire analysis indicates that student's motivation average level is 86,13 which is considered as having a very high criterion. Meanwhile, the highest learning stage of the scores are at the learning planning stage amounted to $97.71 \%$.

Based on the conclusions that have been obtained as a result of this research, there are several suggestions that are expected to be applied related to the effort in improving students' achievement and motivation to write short stories.

The importance of multiliteracy in creative thinkin is to make it easy to create the latest work. Multiliteracy learning will then be developed into a syntax in creative learning models.Applying multimodal in imagination, in order to easily produce imaginative works.

\section{REFERENCE}

Abidin, Yunus. (2015). Pembelajaran Multiliterasi. Bandung: Aditama

Arikunto,S. (2009). Dasar-dasar Evaluasi Pendidikan. Jakarta: Bumi Aksara

Eggen, Paul dan Don Kauchak. (2012). Strategi dan Model Pembelajaran. Jakarta: Indeks 
Erstad, Ola, dkk. (2009). Exploring'Learning Lives': Community Identity, Litercy and Meaning. Journal Literacy Volume 42 Number 2 July 2009 hal 100-106

Haven, K. (2005) Writing Workouts to Develop Common Core Writing Skills: Step-byStep Exercises, Activities, and Tips for Student Success, Grades 2-6. California:Libraries Unlimited.

Julaeha. (2013). Peningkatan kemampuan Menulis Kreatif Cerpen Siswa Kelas VIIIA SMPN 2 Rambupuji Jember Melalui Strategi Sugesti Imaji. Jurnal NOSI Volume 1 Nomor 4 Agsutus 2013 hal 351-360

Laksana. (2013). Creative Writing. Jakarta: Transmedia

Ngalim Purwanto. (1999). Psikologi Pendidikan. Bandung : Remaja Rosdakarya

Sayuti. (2009). Cara Menulis Kreatif. Yogyakarta: Pustaka Pelajar

Sugiyono. (2010). MetodePenelitian Kuantitatif Kualitatif \& RND. Bandung : Alfabeta

Sultan, Rofiuddin, A., Nurhadi, dan Priyatni E. T. (2017). The Effect of the Critical Literacy Approach on Pre-service Language Teacher Critical Reading Skills. Eurasian Journal of Educational Research, 71: 159-174. Ani Publishing 